\title{
Analysis Method of Altman Z Score Modifications to Predict Financial Distress on The Company Go Public Sub Sector of The Automotive and Components
}

\author{
Suhesti Ningsih, SE., MM \\ Febrina Fitri Permatasari, SE., M.Si \\ The College of Economics AAS Surakarta \\ Email: hesti_hegi@gmail.com
}

\begin{abstract}
: This research aims to analyze the variables from methods of Altman Z Score Modification in predicting financial distress in go public company automotive sub sector and component 2012-2016 periods. The results of the analysis using the method of Altman Z Score Modifications show that companies in the automotive sector and sub components of almost every year there are enterprises that are predicted to have experienced financial distress. In 2012 the company predicted experience financial distress is GDYR, the year 2013 there are 2 companies i.e. BOLT and GDYR, the year 2014 they are IMAS GDYR and predictable. In the year 2015 there are 2 companies i.e. IMAS, GDYR and 2016 year whereas LPIN is GDYR, IMAS and PRAS. The results of the analysis of the average value of $\mathrm{Z}$ "Score of years 2012-2016 under 1,1 on go public company automotive sub sector and components according to the analysis of Z" Score of the companies in financial distress condition is GDYR and the IMAS. From the analysis results annually and on average during the period 2012 to 2016 suggest that there are some companies that are predictable in financial distress is evidenced by the value of its $\mathrm{Z}$ "Score under 1,1 .
\end{abstract}

Keywords $\quad$ : Rasio Keuangan, Financial Distress, Z”Score.

\section{Introduction}

Bankruptcy is usually derived from financial hardship (financial distress) that is started when the company failed to meet payment obligations. Financial Distress and early signs of bankruptcy can be revealed through analysis of the data contained in the financial statements. Factors cause the occurrence of financial distress is by economic factors, errors in management, and natural disasters (Sudana; 2011; 249).

A number of studies have been conducted to find out the usefulness of financial ratio analysis to predict the failure or bankruptcy of a company. One study of this prediction is multiple discriminan analysis (MDA) commonly known methods of Altman Z-Score.

According to Yoseph (2012:2) analysis of the financial distress that is 
often used is the analysis of Z-Score model Altman, models and model Springate Zmijewski. The analysis is known for in addition to it's easy, the accuracy in determining the prediction of financial distress is also quite accurate. In this study only use methods of Altman Z-Score and Zmijewski.

Analysis of Z-Score that was first developed by Altman in 1968. In a ZScore modification ( $Z$ Score) this Altman eliminate the variable sales/total assets (STA) because this very price ratio in the industry with the size of the different assets. The variables are still used IE Net Working Capital to Total Assets, the Retained Earnings to Total Assets, Earning Before Interest and $\S$ Taxes to Total Assets, and the Book Value of Equity to Book Value of Debt.

A modified model of Altman Z Score is the median yield - average score of the Group of companies that did not go bankrupt becomes lower compared to the previous model of the bankruptcy. Some research about financial distress by the method of Altman Z Score Modification already done including by Nugroho (2012), Marta (2013), Irfan (2014), Yuniarti Sagho and Merkusiwati (2015).

\section{Literature Review}

\subsection{Financial Ratio Analysis}

The ratio is a measurement tool that is used to analyze a company's financial statements. The ratio describes a relationship between a consideration or a certain amount by the number of the other. According to Bambang Arwana (2001:329), financial ratio analysis is the process of determining important operating and financial characteristics of a company's accounting data and financial statements. The purpose of this analysis is to determine the performance efficiency of the managers of the company that realized in financial records and financial statements. Ratio-the ratio used in this method of Altman can be grouped in three major groups namely liquidity ratios, profitability ratios, solvency ratio and activity ratios.

\subsection{Financial Distress}

Brigham and Gapenski (1997) split the definition of financial distress into several types, namely economic failure, business failure, technical insolvency, insolvency in bankruptcy, bankruptcy and legal. Financial distress occurs before the bankruptcy. Bankruptcy itself is usually defined as a State or situation where companies fail or no longer able to meet the obligations of the debtor because the company is experiencing a shortage and the insufficiency of funds.

Sudana $(2011 ; 249)$ in his book States that the cause of the occurrence of financial distress due to economic factors, errors in management, and natural disasters. The company suffered a failure in its operations will have an impact on financial difficulties. But most of the causes of the occurrence of financial distress either directly or indirectly is the fault of management that happens over and over again. The factors that led to the bankruptcy are common factors, the company's internal factors and external factors of the company. 
International Journal of Economics, Business and Accounting Research (IJEBAR)

Peer Reviewed - International Journal

Vol-2, Issue-3, 2018 (IJEBAR)

ISSN: 2614-1280, http://www.jurnal.stie-aas/ijebar

\subsection{Altman Z-Score Method}

Model of Altman z-score is an indicator to measure the potential bankruptcy of a company. Variables or ratio-financial ratio used in the discriminant analysis model Altman is (Endri, 2009 in Ferbianasari, 2012): Equation of the Altman $x$ first model that is:

$$
\mathrm{Z}=1,2(\mathrm{WCTA})+1,4(\mathrm{RETA})+3,3
$$

$($ EBITTA $)+0,6($ MVEBVL $)+1($ STA $)$

Description:

$\mathrm{Z}=$ Financial Distress Index

WCTA = working capital / total asset

RETA = retained earnings / total asset

EBITTA = earnings before interest and taxes/total asset

MVEBVL= market value of equity / book value of total debt

STA $=$ sales $/$ total assets.

\subsection{Altman Method Z"Score Modification}

According to Altman \& Hotchkiss (2006:248 model Altman modifications can be formulated as follows:

$$
\mathrm{Z} \text { ' } \text { Score }=6.56 \text { WCTA }+3.26
$$

RETA + 6.72 EBITTA + 1.05 BVEBVL

Description:

$$
\begin{array}{ll}
\text { Z"Score } & =\text { Financial Distress Index } \\
\text { WCTA } & =\text { working capital to total } \\
\text { assets } &
\end{array}
$$$$
\text { RETA = retained earning to total }
$$
assets

$$
\text { EBITTA }=\text { EBIT to total assets }
$$

BVEBVL = book value of equity to book value of debt

For Z"score value $<1,1$ it means that the company has financial distress.

For Z"score value between 1,1 until 2,60, then the company condisered located in areas prone/gray.

For Z"score value > 2,60 state that the financial condition of the company is good.

\subsection{Previous Study}

The results of the research conducted by Cahyoo (2012) shows that the Z-Score $=-+3.475(3,116)$ NWCTA + 7, 876RETA $+(2,763)$ EBITTA + 0, 035MVEBVL + 2, 874STA. From the Analysis resulted in a healthy company 6 and 4 companies in financial distress.

In the year 2014 Nugroho also researching on Financial Distress Prediction Analysis. The research results obtained that there are 10 manufacturing companies experiencing financial distress and 78 healthy conditions in the company. Research is also carried out by Irfan and Yuniati (2014) with the result that some companies in the category of financial distress. The variable Net Working Capital To Total Assets and EBIT To Total Assets has significant effects against the level of financial distress at the telecommunications company.

Research conducted by Sagho and Merkusiwati (2015) obtained different results with the above studies is to conduct research on the 11 banking company using the method of altman $\mathrm{Z}$ Score with 
research results that There is no proven companies that they would experience financial distress.

\subsection{Hypothesis}

Based on the description above, it can be formulated the hypothesis:

$\mathrm{H}_{1}$ : There are companies that are having to predict financial distress on the public sector companies go otomaotif and sub components.

\subsection{Theoretical Framework}

MODEL ALTMAN Z"Score
$\mathrm{X}_{1}:$ WCTA
$\mathrm{X}_{2}:$ RETA
$\mathrm{X}_{3}:$ EBITTA
$\mathrm{X}_{4}:$ MVEBVD
\begin{tabular}{|l}
\hline SCORE \\
$\mathrm{Z}>2.67=$ Sehat \\
$1.81>\mathrm{Z}>2.67=$ Abu-Abu \\
$\mathrm{Z}<1.87=$ FinancialDistress
\end{tabular}

Theoretical Framework Scheme

\section{Research Methodology}

This research is a research eksplanatory are cross-time series and cross-sectional or panel data called (pooled data). The technique of determination of the sample in this research is purposive sampling with the criteria used to select the sample is go public company that enter the Automotive sub sector and components during the period 2012-2016.

a. Companies publish annual financial reports for the period 31 December 2012-2016 expressed in rupiah (Idr).

b. Related research company Data available.
Data collection method is a method of the documentary that is secondary data in the form of the financial statements of the company through the page www.idx.go.id

The data analysis method uses quantitative descriptive analysis to predict the onset of the financial distress using methods of Altman Z Score Modification. The descriptive method is a method which is able to explain the problems with regard to the formulation of questions against the independent variable, either only one or more variables (Sugiyono: 2013).

a. Descriptive Quantitative Analysis

The stages performed by the method of Altman Z-Score as follows:

1) Calculate financial ratios on the of Altman Z-Score model, namely:

a) Rasio Modal Kerja/ Total Assets $\left(\mathrm{X}_{1}\right)$

b) Profits Ratios on Hold / Total Assets $\left(\mathrm{X}_{2}\right)$

c) Earnings Ratios before interest and taxes / Total Aset $\left(\mathrm{X}_{3}\right)$

d) Book Value Ratio of Capital / Nilai Buku Hutang $\left(\mathrm{X}_{4}\right)$

2) Doing calculations with Altman modifications via the formula:

$Z^{\prime \prime}=6.56 X_{1}+3.26 X_{2}+6.72 X_{3}$ $+1.05 \mathrm{X}_{4}$

whereas:

Z"Score > 2,6 Health

$1,1>$ Z”Score $<2,6$ Grey

Z'Score $<1,1$ Fiancial Distress Risk 
International Journal of Economics, Business and Accounting Research (IJEBAR)

Peer Reviewed - International Journal

Vol-2, Issue-3, 2018 (IJEBAR)

ISSN: 2614-1280, http://www.jurnal.stie-aas/ijebar

\section{Result and Discussion}

\subsection{Result}

Based on the sample of the research selection criteria then the number of the company that became the sample as much as 64 of 65 companies because one company whose data are incomplete i.e. BOLT in 2012.

\section{Altman Z"Score Modifikasi Method}

The equation Z "Score in the modifications: Z"Score $=6.56 X_{1}+3.26 X_{2}+6.72 X_{3}+1.05 X_{4}$.

Table 5.1

The results of Z "Score Modification Analysis Method year 2012-2016

\begin{tabular}{|c|c|c|c|c|c|c|}
\hline Comp. & & & Score I & & & \\
\hline Code & 2012 & 2013 & 2014 & 2015 & 2016 & \\
\hline ASII & 4,38 & 4,00 & 4,12 & 4,07 & 3,45 & 4,00 \\
\hline AUTO & 4,84 & 6,72 & 6,09 & 5,77 & 4,63 & 5,61 \\
\hline BOLT & & $-1,52$ & 4,77 & 9,85 & 11,23 & 4,86 \\
\hline BRAM & 5,53 & 3,78 & 3,09 & 3,92 & 4,23 & 4,11 \\
\hline GDYR & 0,21 & 0,60 & 0,35 & 0,16 & 0,86 & 0,44 \\
\hline GJTL & 3,58 & 3,23 & 2,95 & 2,20 & 2,65 & 2,92 \\
\hline IMAS & 2,01 & 1,35 & 0,98 & 0,63 & $-0,05$ & 0,99 \\
\hline INDS & 1,93 & 8,68 & 12,26 & 6,18 & 5,22 & 6,85 \\
\hline LPIN & 8,15 & 6,83 & 5,58 & $-0,05$ & $-3,93$ & 3,32 \\
\hline MASA & 2,56 & 2,60 & 2,85 & 3,00 & 1,83 & 2,57 \\
\hline NIPS & 2,64 & 1,85 & 3,05 & 1,73 & 2,29 & 2,31 \\
\hline PRAS & 14,74 & 2,42 & 2,68 & 2,23 & 0,84 & 4,58 \\
\hline SMSM & 6,42 & 7,04 & 6,21 & 6,54 & 7,89 & 6,82 \\
\hline TOTAL & 4,38 & 3,66 & 4,23 & 3,55 & 3,16 & 3,80 \\
\hline
\end{tabular}

Source: the Data processed

The company predicted experience financial distress at thun 2012 is PT
Goodyear Indonesia Tbk with value $\mathrm{Z}$ "Score of 0,21 means less than 1,1. While 
the year 2013 there are 2 companies that have been predicted in the ondisi financial distress with value Z "Score-1.52 IE PT Garuda Metalindo Tbk and PT Goodyear Indonesia Tbk. amounting to 0.60

The results of the analysis in 2014 shows that companies that sign in the category of financial distress are Goodyear Indonesia Inc. with a value of 0.35 followed Indo Mobil Internasional Inc. amounting to 0,98. In 2015 the company predicted in conditions of financial distress are Goodyear Indonesia Inc with Z'Score value of 0,16 , followed by Indo Mobil Internasional Inc of 0.63 and Multi Prima Sejahtera Inc. amounting to-0,05. While in 2016 is forecast in conditions of financial distress are PT Goodyear Indonesia Tbk with a value of 0.86 then Indo Mobil Internasional Inc. with a value of- 0.05 and Prima Alloys Steel Universal Inc. amounting to 0,84 .

\subsection{Discussion}

According to the modification method Altman Z "Score, obtained an analysis results that detected every year in some companies experiencing financial distress predicted. In the year 2012 is detected 1 firm financial distress i.e. Goodyear Indonesia Inc. with Z"Score value 0,21 < 1,1. While the companies that entered the category of gray or less healthy because it has a value of between 1.1 to 2.6 is Indo Mobil Internasional Inc, Indospring Inc, Multi Strasa Asrah Sarana Inc and Nipres Inc. Other companies belonging to the categories healthy because it has a value of $\mathrm{Z}$ "Score greater than 2,6 with the healthiest position is Prima Aloy Steel Universal Inc. that have the highest value.
In 2013 the company predicted to experience financial distress was Garuda Metalindo Inc, Goodyear Indonesia Inc, with a value of $-1.52,0.60$, where the $\mathrm{Z}$ value was $<1,1$. The company in gray is Prima Aloy Steel Universal inc, Indo Mobil Sukses Internasional Inc and Nipres Inc. with a value of $2,421.35$ and 1,85 where the value is > 1,1 and <of 2,6. While other companies fall into the category of companies in a healthy condition because the $\mathrm{Z}$ "Score is greater than 2,6.

The results of the $\mathrm{Z}$ "Score analysis in 2014 showed that there were 2 companies predicted in financial distress conditions with a value of less than 1,1 is Goodyear Indonesia Inc. with a value of 0,35 and Indo Mobil Internasional Inc. of 0,98 . While other companies fall into the category of companies that have a healthy financial condition because they have $\mathrm{Z}$ score of above 2,6.

The calculation Results with Z"Score method in 2015 obtained results that companies that experienced financial distress were Goodyear Indonesia Inc which valued at 0.16 , Indo Mobil Internasional Inc. 0.63 and Multi Prima Sejahtera Inc. amounting to -0.05 where the three had $<1,1$. Three companies included in the vulnerable category experienced financial distress with a Z"score of between 1,1 and 2.6, Gajah Tunggal Inc with a value of 2,2, Nipres Inc. 1.73 and Prima Aloy Steel Universal Inc of 2,23. Whereas other companies include companies that have sound financial health where the $\mathrm{Z}$ "Scoren value is $>2,6$. 
From the analysis result in 2016 obtained results that Goodyear Indonesia Inc. has a $\mathrm{Z}$ score of 0.86 , Indo Mobil Internasional Inc. with a value of -0.05 and Prima Aloy Steel Universal Inc. of 0.84 . These companies have a $\mathrm{Z}$ value of $<1.1$ so it can be concluded that the three companies experience financial distress. Whereas Multi Strasa Asrah Sarana Inc and Nipres Inc.. each has a Z "Score of 1,83 and 2,29 in an unhealthy or gray financial position because of the Z" Score $>$ of 1,1 and $<2,6$.

The results of this study support the research done by Nugroho (2014) who examined the Analysis of Financial Distress Prediction Using the Altman ZScore Modification Model that there were 10 manufacturing companies that experienced financial distress and 78 other companies classified as healthy financial categories. The results of this study are also in line with the results of research conducted by Irfan and Yuniati (2014) with the results of the study are several companies in the financial distress category.

The results of this study contradict the research that has been done by Sagho and Merkusiwati (2015) which examined 11 banking companies using the Altman $\mathrm{Z}$ method "Score proved to be not indicated to experience financial distress.

From the results of Z'Score's analysis per year and the average for the period of 2012 to 2016 shows that there are several companies in the component sub-sector having a $\mathrm{Z}$ "Score less than 1.1. This shows that the hypothesis is accepted which is proven that there are several companies going public in the automotive sub-sector and the components predicted in financial distress.

\section{Conclusion}

Based on the results of the analysis and testing of data and discussion, the following conclusions can be drawn:

Analysis using the Altman Modification Z method "Score obtained results from 2012-2016 of the 13 companies detected there were 7 companies with financial distress, the companies were GDYR, BOLT, IMAS, LPIN, NIPS, MASA and PRAS.

From the calculation of the average for 5 years the value of $\mathrm{Z}$ "Score shows that it is predicted that there are 2 companies that experience financial distress, namely GDYR and IMAS with a $\mathrm{Z}$ value" Score $<1,1$.

\section{Suggestion}

For company managers in managing the company's finances must be more effective and efficient so that the company does not experience financial distress. For investors can be used as a reference in making decisions to invest by looking at companies that show companies that have good financial performance. For further researchers it is better to examine companies in other sectors in the property sector, banking or companies in conventional sharia and index indexes, in addition also use other methods like Springeti or the Olhson and Grover methods.

\section{Reference}

Altman, E. I. 2000. Predicting Financial Distress of Companies; Revisiting 
International Journal of Economics, Business and Accounting Research (IJEBAR)

Peer Reviewed - International Journal

Vol-2, Issue-3, 2018 (IJEBAR)

ISSN: 2614-1280, http://www.jurnal.stie-aas/ijebar

the Z-score and Zeta Models. Journal of Banking and Finance 1(2); 1968 - 2000.

Brigham, F. and Gapenski.1997. Financial Management: Theory and Practice.(Fort Worth: The Dryden Press).

Cahyono, Wijaya Adi. 2013. Prediksi Kebangkrutan Perusahaan Pertambangan Batu Bara yang Listing di Bursa Efek Indonesia Periode 2011-2012 dengan Menggunakan Analisis Model Zscore Altman. E-Jurnal. Malang: Fakultas Ekonomi dan Bisnis Universitas Brawijaya.

Ferbianasari, Hilda Nia. (2012). Analisis Penilaian Financial Distress Menggunakan Model Altman ZScore pada Perusahaan Kosmetik yang Tercatat di Bursa Efek Indonesia. Surabaya: Universitas Negeri Surabaya.

Fitriani Rahayu, I Wayan Suwendra, Ni Nyoman Yulianthini (2016) Analisis Financial Distress Dengan Menggunakan Metode Altman ZScore, Springate, Dan Zmijewski Pada Perusahaan Telekomunikasi; $e$ Journal Bisma Universitas Pendidikan Ganesha Jurusan Manajemen Volume 4

Irfan Mochamad, Tri Yuniarti (2014). Analisis Financial Distress Dengan Pendekatan Altman Z"-Score Untuk Memprediksi Kebangkrutan Perusahaan Telekomunikasi. Jurnal
Ilmu \& Riset Manajemen Vol. 3 No. 1 (2014)

Nugroho, M. I. D. 2012. Analisis Prediksi Finansial Distress dengan Menggunakan Model Altman Modifikasi 1995. Skripsi. Universitas Diponegoro. Semarang.

Peter, Yoseph, 2012. "Analisis Kebangkrutan Dengan Metode Zscore Altman, Springate dan Zwejwski pada PT. INDOFOOD Sukses Makmur Tbk Periode 20052009."Akurat Jurnal Ilmiah Akuntansi Nomor 04 Tahun ke-2 Januari-April 2011.

Riyanto, Bambang. (2001). Dasar-Dasar Pembelanjaan Perusahaan. Yogyakarta: BPFE.

Sagho, Maria Florida dan Merkusiwati, Ni Ketut Lely Aryani 2015. Penggunaan Metode Altman Z-Score Modifikasi Untuk Memprediksi Kebangkrutan Bank Yang Terdaftar Di Bursa Efek Indonesia. E-Jurnal Akuntansi Universitas Udayana Vo. 11.3 hal 730-742

Sofyan Syafri. 2009. Analisis Kritis atas Laporan Keuangan. Jakarta: PT. Raja Grafindo Persada.

Sudana, I. M. 2011. Manajemen Keuangan Perusahaan; Teori dan Praktek. Erlangga; Jakarta.

Sugiyono. 2013. Metode Penelitian Pendidikan (Pendekatan Kuantitatif, Kualitatif, dan R\&D).Bandung : Alfabeta. 
International Journal of Economics, Business and Accounting Research (IJEBAR)

Peer Reviewed - International Journal

Vol-2, Issue-3, 2018 (IJEBAR)

ISSN: 2614-1280, http://www.jurnal.stie-aas/ijebar

Yuliastary, Etta Citrawati dan Made Gede Score Altman, Springate, Zmijewski. Wirakusuma. 2014. Analisis E-Jurnal Akuntansi Universitas

Financial Distress dengan Metode ZUdayana 6.3:379-289. 